\title{
On the Track of Lost Editions in Italian Religious Libraries at the End of the Sixteenth Century: A Numerical Analysis of the RICI Database
}

\section{Giovanna Granata}

The bibliographical coverage of early printing and publishing in Europe has widened enormously in previous decades due to the development of electronic databases and collective catalogues. The multitude of records contained in these provide a reasonably accurate idea of what was published in the fifteenth and sixteenth centuries. However, at the same time this increased availability of data has also raised the bar of expectations; in particular, it has increased the interest of scholars in the phenomenon of lost editions. Now that it is easier to explore the quantitative distribution of surviving copies for each edition, scholars have also been faced, in quite dramatic terms, with the question of the potential number of unknown editions, those for which no copies survive as testimony. ${ }^{1}$

There have been two different approaches to this problem. The first adopts an inferential methodology, based on a statistical projection of the data currently available to us; ${ }^{2}$ the second uses an analytical methodology, based on the investigation of specific cases and on the examination of different documentary sources (either archival or bibliographical). ${ }^{3}$ The advantage of the first approach is that it provides a degree of global data, but at the same time this data is offered without any possibility of verification; the second is potentially able to reconstruct the main elements of specific unknown editions, but

1 On this subject see the important remarks of Neil Harris, 'La sopravvivenza del libro ossia appunti per una lista della lavandaia', Ecdotica, 4 (2007), pp. 24-65 and 'L'unicum in biblioteca: per un'analisi della sopravvivenza del libro antico', in Maria Paola Barlozzini (ed.), Gli incunaboli e le cinquecentine della Biblioteca di San Gimignano (San Gimignano: Comune, 2007), vol. II, pp. 51-64.

2 See Jonathan Green, Frank McIntyre and Paul Needham, 'The Shape of Incunable Survival and Statistical Estimation of Lost Editions', Papers of the Bibliographical Society of America, 105 (2011), pp. 141-175.

3 See for example the studies of Jean-François Gilmont on Jean Calvin, Jean Crespin and Carolus Scribani, now collected in Jean-François Gilmont (ed.), Le livre \& ses secrets (Geneva: Droz, 2003). 
its overall view of a phenomenon for which huge numbers, in the tens of thousands, have been hypothesized is inevitably limited and fragmentary. ${ }^{4}$

In order to merge the different benefits of the two methodologies, it would be necessary to compare the data recorded by modern bibliographical tools with the data taken from sources which are contemporary with the dates of publication of the books in question. The data from these contemporary sources should also be as extensive and detailed as possible in order to ensure both that it is quantitatively significant and bibliographically reliable.

This kind of source, both comprehensive and detailed, is in the nature of things extremely rare. Scholars working in the field of early printed books are increasingly interested in the exploitation of documentary sources, either newly discovered or long familiar, ${ }^{5}$ but the results it has been possible to obtain are generally disappointing when they are compared with the size of the gaps in our bibliographical knowledge outlined by the statistical approach. ${ }^{6}$

An important exception to this prevailing situation, however, is the documentation accumulated between 1598 and 1603 as a result of the investigation

4 These fluctuations depend on the mathematical model adopted for calculation; see on this topic the discussion of Green, McIntyre and Needham, 'The Shape of Incunable Survival', who estimated that the number of lost sixteenth-century editions could be either in the range of $40-60 \%$ or in the range of $35-50 \%$, depending on the statistical treatment.

5 See for example Alexander S. Wilkinson, 'Lost Books Printed in French before 16o1', The Library, 10 (2009), pp. 188-205, who resorted to the historical French catalogues of François de La Croix du Maine (1580) and Antoine du Verdier (1585), in order to explore the problem of French vernacular books now lost, by mapping their data to the French Vernacular Book (hereafter: FVB) database entries. Studies on the book trade have also been focusing on some inventories which, from a quantitative point of view, are highly significant. See, for example, the Zornale of Francesco de Madiis, first mentioned by Horatio Brown in his study on the history of printing in Venice in 1891, the interest of which as a source of evidence for many lost editions has recently been emphasized by Neil Harris and Cristina Dondi, 'Oil and Green Ginger. The Zornale of the Venetian Bookseller Francesco de Madiis, 1484-1488', in Malcolm Walsby and Natasha Constantinidou (eds.), Documenting the Early Modern book world: Inventories and catalogues in manuscript and print (Leiden: Brill, 2013), pp. 341-406. An extensive survey of the documentary sources of this kind can be found in Angela Nuovo, The Book Trade in the Italian Renaissance (Leiden: Brill, 2013).

6 For example, the sample of references used by Wilkinson, 'Lost Books' for mapping data to the FVB database entries in his survey on lost French vernacular books amounted to 5,639 editions, while the estimate of the lost editions made by Neil Harris based on a statistical projection of editions surviving in one or two copies recorded in FVB results in some 59,000. See Neil Harris, 'The Italian Renaissance book: Catalogues, censuses and survival', in Malcolm Walsby and Graeme Kemp (eds.), The book triumphant. Print in transition in the Sixteenth and Seventeenth centuries (Leiden: Brill, 2011), pp. 26-56, at p. 54. 
carried out by the Congregation of the Index into the books held by the Italian religious orders, in the wake of the so-called Clementine Index in 1596 and the subsequent campaign of control and censorship. ${ }^{7}$ Each order was required to provide a description of all the books - not just those which were prohibited or regarded as suspicious - which were held in their communal library as well as those possessed by individual monks and nuns in their cells: the amount of data surveyed and recorded in the resulting manuscript inventories is correspondingly vast.

Romeo De Maio, who was the first to emphasise the importance of these lists for bibliographical studies, described them as "the greatest national bibliography of the Counter-Reformation". This definition, although evidently anachronistic and misleading in a strictly technical sense, has been generally accepted as an appropriate one, since it highlights the two main features of these remarkable documents: their range of coverage and their analytical depth. The census involved almost 2,200 convents and monasteries belonging to thirty-one religious orders throughout Italy, who recorded the books in their possession, following guidelines for their cataloguing which were supplied by the Congregation, with a high degree of accuracy in order to ensure that these editions, whether prohibited, subject to expurgation, or permitted for reading, were correctly identified.

\section{The Enquiry of the Congregation of the Index as a Source for Lost Editions}

The relevance of this source to the improvement of our current knowledge of early printing and publishing, and particularly to the search for evidence of lost editions, was immediately appreciated. Several scholars attempted to

7 The documentation is mainly kept in the Vatican Library, mss. Vaticani Latini 11266-11326: see Marie-Madeleine Lebreton and Luigi Fiorani, Codices Vaticani Latini. Codices 11266-11326. Inventari di biblioteche religiose italiane alla fine del Cinquecento (Vatican: Biblioteca Apostolica Vaticana, 1985). Some other documents have recently been found, held by other institutions: see Roberto Rusconi, 'I religiosi e i loro libri in Italia alla fine del secolo XvI', in Rosa Marisa Borraccini, Giovanna Granata and Roberto Rusconi, 'A proposito dell'inchiesta della S. Congregazione dell'Indice dei libri proibiti alla fine del '500', Il capitale culturale, 6 (2013), pp. 13-45, at p. 17 .

8 Romeo De Maio, 'I modelli culturali della Controriforma. Le biblioteche dei conventi italiani alla fine del Cinquecento', in Romeo De Maio (ed.), Riforme e miti nella Chiesa del Cinquecento (Naples: Guida, 1992), pp. 355-370, p. 363. 
analyse a selection of the lists - the sheer magnitude of the documentation makes it impossible to examine all the available data - from this perspective. ${ }^{9}$

The results of these surveys were encouraging, but they were in effect preliminary skirmishes when measured against the vast amount of data which the documents assembled by the Congregation could potentially make available.

However, new opportunities for research are emerging from the database "Le biblioteche degli ordini regolari in Italia nel Xvi secolo" created by the research group 'Ricerca sull'Inchiesta della Congregazione dell'Indice' (the database is hereafter referred to as RICI );10 in this database, all the manuscript lists compiled by the religious orders in Italy are being transcribed and then analytically indexed in order to ensure a comprehensive and integrated approach to the bibliographical data found in the entire range of the documentation.

The working methodology involves a systematic validation of the editions listed for each religious house by checking against the most current reference

9 See for example Gianvito Resta and Giuseppina Zappella who proposed supplementing the bibliography of Sicilian and Neapolitan early printing respectively by relying on data recorded by the Franciscans in Sicily which had just been published by Diego Ciccarelli in his La circolazione libraria tra ifrancescani di Sicilia (Palermo: Officina di studi medievali, 1990): Gianvito Resta, 'La stampa in Sicilia nel Cinquecento', in Marco Santoro (ed.), La stampa in Italia nel Cinquecento (Rome: Bulzoni, 1992), pp. 777-841; Giuseppina Zappella, 'Alla ricerca del libro perduto: supplemento "virtuale" agli annali della tipografia napoletana del Cinquecento' in Vincenzo De Gregorio (ed.), Bibliologia e critica dantesca. Saggi dedicati a Enzo Esposito. 1: Saggi bibliologici (Ravenna: Longo, 1997), pp. 243-293. More general remarks are developed by Ugo Rozzo, focusing on incunabula, 'Una fonte integrativa di ISTC: l'inchiesta della Congregazione dell'Indice del 1597-1603', in Rosa Marisa Borraccini and Roberto Rusconi (eds.), Libri, biblioteche e cultura degli Ordini Regolari nell'Italia moderna attraverso la documentazione della Congregazione dell'Indice. Atti del Convegno Internazionale (Macerata 30 maggio - 1 giugno 2006) (Vatican: Biblioteca Apostolica Vaticana, 2006), pp. 215-250 and, based on some Servite lists, by Flavia Bruni, 'The Book Inventories of Servite Authors and the Survey of the Roman Congregation of the Index in Counter-Reformation Italy', in Walsby and Constantinidou (eds.), Documenting the Early Modern book world, pp. 207-220.

10 The database is the main product of the research group RICI (Ricerca sull'Inchiesta della Congregazione dell'Indice), led by Roberto Rusconi and at work since 2000, with the involvement of several Italian universities, cultural Institutes and religious Orders. The papers published by the research group, updated to 2013, are listed in Borraccini, Granata and Rusconi, 'A proposito dell'Inchiesta', pp. 36-45. The general features of the database are documented by Giovanna Granata, 'Struttura e funzionalità della banca dati "Le biblioteche degli ordini regolari in Italia alla fine del secolo XvI', in Borraccini and Rusconi (eds.), Libri, biblioteche e cultura, pp. $285^{-308}$. The database in now available through the Vatican website: $<$ http.//rici.vatlib.it $>$. 
sources for early printing and publishing, so as to be able to identify those which correspond to editions already known ('matched' editions) and those which do not ('unmatched' editions). This second category of 'unmatched' editions is clearly an important potential resource from which, taking due methodological caution in order to single out possible ghosts, it is possible to reconstruct a plausible (at least) hypothetical list of editions which are unrecorded today because no copies of them survive.

The most innovative character of the database and its main advantage compared with previous research on the lists relate to the comprehensiveness of the information presented in the database, the number of unrecorded (unmatched) editions it contains and as a result the extent of the "hypothetical lists of missing editions" which can be extracted.

Although the original documentation has not yet been completely analysed and the work of transcribing, transferring and indexing is still in progress, the editions which have been successfully identified in the available bibliographical sources already number about 27,500: a considerable figure which confirms the significance of the documentation and already enables us to draw up some overall assessments of the bibliographical nature and reliability of the data it contains." ${ }^{11}$ This figure for identified editions may increase to a limited extent, i.e. a few more new editions will eventually be found and matched with currently recorded editions, although it is more probable that a wider distribution of the already identified editions among the holdings of religious houses will be found.

The trend characterizing the editions which have not been matched in bibliographical sources is quite different: at present they number approximately 43,500 and, as the work of transcribing and identifying continues, this number increases at a faster rate than that of the identified editions. ${ }^{12}$

A significant reason for this increase lies in the high number of items which are difficult to identify because the descriptions of them found in the original

11 Some preliminary attempts in this regard have been made by the author of the present paper on different occasions; for a bibliography see Borraccini, Granata and Rusconi, 'A proposito dell'Inchiesta'.

12 In 2006 the number of matched editions amounted to 25,400 versus 20,900 unmatched editions, see Granata, 'Struttura e funzionalità'. About 5 years later, the former total was little varied (about 26,00o) while the number of the unmatched editions had almost doubled (about 41,00o): see Giovanna Granata, "'La più grande bibliografia nazionale della controriforma":il trattamento informatico dei dati dell'Inchiesta della Congregazione dell'Indice', in Roberto Rusconi (ed.), Il libro antico tra catalogo storico e catalogazione elettronica (Rome: Scienze e Lettere, 2012), pp. 133-154. The data discussed in this paper is updated to May 2014. 
manuscript inventories are more or less full of omissions; nevertheless, these items are still indexed in the database but only at the level of the title of the work they contain or with a partial description. If we subtract these cases from the above-mentioned total of 43,500 , about 21,850 editions remain, which can then be subjected to a more detailed and consistent analysis in order to ascertain whether they are in effect the traces of lost editions. ${ }^{13}$

This figure is much more limited in respect to the total - just over half - but it is no less difficult to handle properly; in such a large amount of data, there is inevitably a reasonably high risk of creating unwittingly the 'deceptive appearances' of apparent editions which are the bane of serious bibliography. To make matters worse, moreover, these appearances, besides taking the form of ghosts, can also depend on the selection of the bibliographical sources used to check the data. In order to minimize this risk, preference has intentionally been given to large and long-established online databases, in what is a strict hierarchy of consultation.

In connection with these points, an empirical test carried out by the author of the present article in 2004 on about one hundred unmatched editions from the database, ${ }^{14}$ showed that in the case of at least twenty-one of them, all sixteenth-century Italian editions, the failure to identify and match was possibly due to the use of the Italian national census of sixteenth-century Italian editions (Edit16) as the exclusive source for the matching, especially when we remember a fundamental aspect of the census: that it includes only those editions found in Italian libraries..$^{15}$ It is worth noting that for fourteen of these twenty-one Italian editions which could not be found in Edit16, records were retrieved, through a search of their online catalogues, in German and French libraries. Such a result was to be expected of course: the notable survival of Italian editions held outside Italy is well known to bibliographers and the phenomenon is made even more apparent to present-day researchers through the

13 The precise figures are these: there are currently 21,620 editions divided into: (a) 13,242 editions without date of printing (and among them 8,86o without any publication/printing data); (b) 1,280 dated, but without place of printing and publisher/printer; (c) 6,850 dated and with place of printing, but without name of publisher/printer; (d) 265 with date and name of printer, but without place of printing. The remaining 21,846 out of the total of 43,466 form the sample used for the present paper.

14 Giovanna Granata, 'Le biblioteche dei religiosi in Italia alla fine del '6oo attraverso l'Inchiesta della Congregazione dell'Indice. A proposito di libri scomparsi: il caso dei francescani Osservanti di Sicilia', in Maria Grazia Del Fuoco (ed.), Ubi neque aerugo neque tinea demolitur. Studi offerti in onore di Luigi Pellegrini per i suoi settant'anni (Naples: Liguori, 2006), pp. 329-406.

15 See Edit16. 
increasingly broad coverage provided by national and international bibliographical databases. The extent of its impact, though, on this small sample of sixteenth-century editions is still very striking.

In the same way, further analysis of the sample clearly revealed a series of cataloguing errors on the part of those who compiled the lists, mostly due either to trivial misunderstandings or to the inadequacies of the descriptive methodologies employed at the end of the sixteenth century, when some basic distinctions between bibliographical entities were still unknown, resulting in often inappropriate descriptions of some more complex bibliographical units, such as multi-level or collectanea editions. Such errors were not detected during the construction phase of the RICI database, which involved a straightforward comparison of existing bibliographical sources; they emerged only in the course of the more careful analysis - sometimes with book in hand or working with digital images of the cluster of editions which had been misidentified carried out for the sample.

In this way the in-depth analysis carried out for the sample enabled us to identify just under half the editions which had initially been classified as 'unmatched'; despite this success, fifty-two occurrences of unidentified editions remained. A direct examination of these volumes - assuming it were possible to identify where the copies originally held by the monastic libraries and described in the lists are currently held - might serve to clarify the difficulties of interpretation, i.e. whether they are the result of erroneous descriptions on the part of the friars and monks who compiled the lists or whether they are authentic bibliographical rarities instead of lost editions. Yet even in the absence of direct examination of the copies (which would in any case be realistically impossible on the scale of the documentation), such unresolved entries can still be taken as contemporary documentary evidence for the existence of hypothetical unrecorded lost editions.

To sum up, the sampling survey confirms the need to be extremely cautious in our approach to the $21,85^{\circ}$ editions contained in the RICI database which remain hitherto unidentified and it helps us to define the major problems involved in identifying them, but it still does not provide useful elements for the overall analysis of the rest of the documentation. ${ }^{16}$

16 One of the methodological hypotheses requiring verification has been partially confirmed. This is the hypothesis that it is possible to use the distribution of copies throughout the libraries of the religious orders (i.e. the overall number of copies for each edition) as a filter for the identification of actual editions now lost to us, on the assumption that unmatched editions for which a very high number of copies are recorded are more likely to be genuine lost editions, in contrast with unmatched editions for which only a low 
Many factors determine the impact of these problems: internal ones, relating to the characteristics of the books themselves which are described in the lists, ${ }^{17}$ or external ones, relating in particular to our ignorance of the ways in which the census was carried out - whether on the basis of previously existing inventories or by examining each book again in hand, by more or less bibliographically experienced friars, hurriedly or at leisure, and so on.

For this reason the hundred editions covered in the sample cannot be used as the basis for any general deductions; and even if this were the case, a statistical approach would be able to provide merely numerical data. Only a systematic examination of the data would obtain a significant set of robust bibliographical references. The existence of the RICI database is intended to facilitate such a systematic and wide-ranging examination and it remains a goal for the future. It is already possible to use the vast mass of available data which is transcribed and recorded in the database in connection with specific bibliographical questions, such as those relating to individual authors or printers. ${ }^{18}$ For a more global approach to tackling all 21,850 unmatched editions, some preliminary operations of filtering and organising are necessary in order to create a list of the most significant and relevant cases.

number of copies are recorded. However it is not possible to apply this principle as a filter too rigidly. While a very high number of copies would strongly suggest that an edition must have existed (but is now lost) or perhaps still exists (but is now rare or forgotten), there is no evidence, on the other hand, that a single occurrence (i.e. a single copy) has of necessity to be seen as a bibliographical ghost. Moreover, in cases where an average number of copies - neither particularly high nor particularly low - has been recorded, there is evidence of repeated errors in the cataloguing, meaning that, despite the plural occurrences in the lists, these editions can be interpreted as bibliographical ghosts (albeit documented more than once). See Granata, 'Le biblioteche dei religiosi'.

The lists for example clearly show some problems in recording incunabula, possibly because these publications were more unfamiliar than sixteenth-century editions: see Granata, 'Le biblioteche dei religiosi'.

At least two recent studies which use the database as a source for early printing should be mentioned: the survey of the lost editions of Girolamo da Palermo's Confessionario by Rosa Marisa Borraccini in the present volume, 'An Unknown Best-Seller: the Confessionario of Girolamo da Palermo'; see also Rosa Marisa Borraccini, 'Il Confessionario di Girolamo da Palermo: un long seller sconosciuto', in Borraccini, Granata and Rusconi, 'A proposito dell'Inchiesta', pp. 28-36; and the study by Edoardo Barbieri, 'Per monialium poenitentium manus. La tipografia del monastero di Santa Maria Maddalena alla Giudecca, detto delle Convertite (1557-1561)', La Bibliofilia, 113 (2011), pp. 303-353, where RICI data is given in the bibliography. 


\section{A Quantitative Approach to the RICI Documentation}

With this aim in mind, the proposed methodology uses the ratio of the total number of unmatched and matched editions as a threshold value in order to identify some possible trends as well as anomalies and critically significant cases. The value of this ratio is calculated to be around 0.8 : as a result, the cases where there is greatest divergence, i.e. when the number of unmatched editions differs significantly from the number of matched ones, can be singled out as being of particular interest. Thus the threshold value ratio has been applied in order to highlight anomalous authors (i.e. those who diverge significantly from it); for each of these the ratio of unmatched and matched editions has been calculated and the resulting values have been sorted along a scale from maximum to minimum. The total number of authors analysed stands at 5,518.19 On the basis of the calculated threshold value of the ratio, they have been grouped in four separate subsets whose characteristics are discussed below.

\section{Subsets A and B: Authors with no Unmatched or Matched Editions}

First of all, for a large number of authors $(2,883)$, corresponding to slightly more than half the total $(52.2 \%)$, only matched editions are recorded; the ratio of unmatched to matched editions therefore measures o (subset A). In theory, this set could potentially be useful in identifying examples of authors whose works have a higher survival rate and/or have been more widely recorded in catalogues and bibliographies. In fact, it is predominantly constituted of authors with a low number of editions to their name; for the vast majority of them $(2,698)$ the editions listed under their names number no more than two or three; only for ten authors does this number rise to between ten and twenty. ${ }^{20}$ As will be obvious, the data is therefore insufficient for any analysis in terms of survival rates and coverage.

19 The total number of authors in the database is currently higher (about 8,00o). For the purpose of the present analysis, the authors considered are only those indexed in the sample of 21,850 unmatched editions as well as those in the 27,500 matched ones, excluding editions for which the recorded bibliographical information is imperfect. Moreover the analysis has been carried out on authors as main entries, i.e. where they are chiefly responsible for the creation of the work, with the exclusion of cases where they are editors or translators.

The list of these last authors, ordered by number of editions, is: Manuel Chrysoloras (20), Orazio Lombardelli (14), Giacomo Novello (13), Girolamo Mercuriale (12), Publius Papinius Statius (12), Irenaeus (11), Pandolfo Collenuccio (11), Gian Giorgio Trissino (10), Aphthonius (10), Marco Mantova Benavides (10). 
The subset can probably be best interpreted in a negative sense: since the number of matched editions is consistently low, the absence of unmatched editions is not significant; in other words, there are no authors in this subset for whom the absence of unmatched editions means that it is possible to exclude or limit a priori the eventuality of unknown editions (and among them possibly missing works). This is a minimal conclusion which, at least, has the advantage of not contradicting what has already been assumed on other grounds, namely, that the phenomenon of lost editions is fairly extensive. The problem remains in assessing the detail of the phenomenon, i.e. which authors and how many are involved.

At the other end of the spectrum, there is a very limited set of authors (subset B) for whom there are only unmatched editions (i.e. $o$ is the value for matched editions): there are 509 of these, i.e. $9.2 \%$ of the total. Quite apart from this very low figure, it should be noted that the distribution of the number of editions among these authors is very low, even lower than with the authors in subset $\mathrm{A}$, which therefore again means that this data is inadequate for the identification of large-scale trends.

To be precise, for a significant proportion of the 509 authors (447), just one edition is registered; there are about sixty authors with two or three editions while those with four or five editions can be counted on the fingers of one hand. These are the editions published by the Jesuates, as a corporate entity (and name entry), ${ }^{21}$ together with the works of the observant Franciscan preacher Giacomo della Marca, ${ }^{22}$ and those of the canon regular Eusebio Corrado. $^{23}$

21 For the Jesuates, the database documents some unknown editions of the Indulgentie (or privileges which they had been granted), printed between 1568 and 1595: RICI BIB 61722, $8633,64071,35899$.

22 For Giacomo della Marca there are five unmatched editions of his Confessione, all printed in Italy in the sixteenth century and all attested in a single copy only: two Venetian editions (printed by Bernardino Bindoni in 1538 and by Stefano Bindoni in 1549, respectively RICI BIB 46888 and 76530 ) and three editions from Naples (printed by Orazio Salviani in 1589 and by Giovanni Giacomo Carlino in 1596 and 1597, respectively RICI BIB 61441, 45633 and 50790). On Giacomo della Marca and his works, see Carla Casagrande, 'Giacomo della Marca, santo', Dizionario Biografico degli Italiani, 54 (2000), pp. 214-220.

23 For Eusebio Corrado there are four unmatched editions. At least one of them (RICI BIB 57009) can be identified with ISTC iao1324000 (= IGI 1043); the remaining three are two further incunabula (RICI BIB 47244 and 48277 , which is probably a ghost) and a sixteenthcentury Italian edition (RICI BIB 47623: De dignitate canonicus reg., Florence, Carlo di Giovanni Stefano, 1512) not known to Edit16. On Eusebio Corrado, see Katherine Walsh, 'Corrado, Eusebio', Dizionario Biografico degli Italiani, 29 (1983). 
It is clear that the numbers derived from this subset, as with subset A, do not give prominence to certain authors over others. Although, mathematically speaking, the ratio of unmatched and matched editions leads to an infinite number, it is in fact unable to reveal cases which are abnormal. Moreover, for authors with only unmatched editions, unlike the case of subset A, it is possible to recalculate the value of the denominator on the basis of the number of editions known from modern bibliographical sources, thus obtaining values which are at least more plausible in measuring the extent of the phenomenon.

For example, in the case of Giacomo della Marca seven sixteenth-century editions are known while four incunabula are now recorded for Eusebio Corrado, lowering their respective ratios to 1.5 and 1 . In the case of the Jesuates there are seventeen recorded editions, making the ratio value o.2.

However, what is of real relevance in relation to this set of authors is not the infinite value of the ratio, but the low value of numerator and denominator. Rather than indicating (by the calculus of the fraction) a very high number of books which have been lost for each author, they reveal a low circulation rate of works by these authors specifically within the libraries of the religious orders, though not necessarily elsewhere. ${ }^{24}$

In short, they are 'marginal' authors and it is therefore unsurprising if their books, which were already 'rare' in the past, survive today in just a few copies or even do not survive at all. This serves to confirm what is known as a general tendency but the subset also enables us to carry out more detailed analysis.

\section{Subset C: Authors Below the Threshold Value}

More effective elements can be obtained by analysing the remaining 2,126 authors: for these it is possible to calculate the ratio of matched and unmatched editions as values equal to or greater than one. As a consequence, it also becomes possible to observe the resulting trend in relation to the threshold defined by the overall average for the database as a whole.

For over half these authors $(1,189$, equal to $21.6 \%$ of the total $)$, the values are below $0.8 \%$; in other words the ratio of unmatched and matched editions is

24 By way of example, the authors with three unmatched editions and no matched editions are: Andrea Alchero (d. 1574), Vincenzo Ercolani (d. 1539), Georges de Bruxelles, Lorenzo Gherardi (fl. 16th cent.), Giovanni da L'Herba (fl. 1536), Antonio Miserocchi, Sebastião Morais (1534-1588), Ippolito Musso, Cristoforo Scanello (d. about 1593), Michele Verino (about 1469-1487). 
lower than the threshold or reference value (these authors form subset $\mathrm{C}$ ). It is interesting to observe that, again, the number of editions for each author is quite low, even if in this case values are clearly less uniform and display a more marked variability. To be more precise, there are 444 authors with more than ten editions (matched and unmatched), while there are more than fifty editions each for approximately sixty authors. ${ }^{25}$

Among them those authors clearly stand out for whom the coverage in bibliographies and catalogues is both more accurate and comprehensive, as a result of the interest shown in them by literary historians, critics and book collectors. There are, for example, in this list numerous classical authors, especially (listed here by total number of editions in decreasing order): Cicero, Ovid, Terence, Horace, Plutarch, Valerius Maximus, Sallust, Julius Caesar, Galen, Aesop, Pliny the Elder, Livy, Seneca, Suetonius, ${ }^{26}$ together with several leading Italian Renaissance humanists and poets, above all Petrarch, Boccaccio, Ariosto and Tasso, ${ }^{27}$ but also Pietro Bembo, Aldo Manuzio, Jacopo Sannazzaro and Lorenzo Valla ${ }^{28}$ as well as other scholars and polygraphs of the time such as Paolo Giovio, Francesco Sansovino, Lodovico Dolce, Girolamo Ruscelli, Ludovico Pittorio. $^{29}$

Constraints of space do not allow us to look at specific examples; it is however worth underlining how these findings indirectly corroborate the methodological approach that has been adopted for filtering the data. The application of the threshold value, defined as the ratio of unmatched to matched editions,

25 It should be noted that the values are calculated in terms of the number of editions. As a consequence the data is not very useful as a measure of how widespread these authors were among the Italian religious orders at the end of the sixteenth century. To ascertain this it would be more appropriate to look at the number of copies, as the present author has proposed, in 'Biblioteche religiose e circolazione libraria alla fine del '500. Prime note quantitative' in Essays in honor of Roberto Coroneo (forthcoming).

26 The number of the editions are: Cicero (459 matched vs. 321 unmatched), Ovid (138 vs. 85), Terence ( 84 vs. 54 ), Horace (92 vs. 41 ), Plutarch ( 85 vs. 25 ), Valerius Maximus (73 vs. 31 ), Sallust (61 vs. 26 ), Julius Caesar ( 65 vs. 15 ), Galen (47 vs. 30 ), Aesop ( 45 vs. 26 ), Pliny the Elder ( 50 vs. 14 ), Livy (43 vs. 19), Seneca ( 38 vs. 17 ), Suetonius ( 37 vs. 13). The ratio of unmatched and matched editions for all the authors varies between 0.2 and 0.6 , thus remaining far below the standard value of 0.8 ; only for Cicero does the ratio increase to 0.7 , probably owing to the high number of editions.

27 The number of editions are: F. Petrarca (99 matched editions vs. 51 unmatched), G. Boccaccio ( 52 vs. 19), L. Ariosto (53 vs. 11), T. Tasso (69 vs. 26 ).

28 The number of editions are: P. Bembo (64 matched editions vs. 26 unmatched), A. Manuzio (50 vs. 40 ), J. Sannazaro (69 vs. 19), L. Valla (48 vs. 26 ).

29 The number of editions are: P. Giovio (64 matched editions vs. 17 unmatched), J. Sansovino (61 vs. 16 ), L. Dolce (48 vs. 20 ), G. Ruscelli (45 vs. 23 ), L. Pittorio (35 vs. 28 ). 
indicates negative values (i.e. with a low number of unmatched editions) for those authors whose survival has indeed been less seriously affected. Thus, it is not by chance that, when sorting data by a decreasing ratio value, Ludovico Ariosto, one of the sixteenth century authors whose editions are most widely recorded in bibliographies, occupies the leading position. ${ }^{30}$ In a similar way, on the basis of these findings, we can expect to find among the authors with positive values, i.e. those exceeding the threshold value of 0.8 , some at least of those for whom the survival of their editions is known to have been more seriously affected.

However, before introducing the analysis of this subset, some further points need to be taken into consideration. Firstly, on the significance of the subset: the low ratio of unmatched and matched editions does not imply that for these authors the possibility of lost editions is to be excluded, but rather that we can assume the possibility has a smaller impact, bearing in mind the fact that the category of unmatched editions may also contain ghosts and other kinds of errors. So the authors included in this subset cannot be regarded as a priority if our aim is to find those authors whose results have a higher statistical significance. It does not of course follow from this that these authors are of no interest in terms of more detailed analysis.

A second point can be made about the internal distribution of data within the subset: it should be noted that among the authors who remain below the threshold value, a significant proportion of them vary widely from it, with a low ratio of unmatched to matched editions. In 914 cases (corresponding to $77 \%$ of the subset) the ratio is below 0.5 or, in other words, the unmatched editions do not amount to more than half the matched ones. In particular in 876 cases their number is less than ten. Thus a large part of this subset can be seen as an extension of subset $\mathrm{A}$, confirming again the extent of the phenomenon of 'unknown editions' in the data base, but, unlike subset $\mathrm{A}$, it also yields more detailed data on the phenomenon.

Looking at the higher range of the spectrum, for just 275 authors out of the total of 1,189, the calculated ratio is close to 0.8 and among them only 163 (corresponding to $13.7 \%$ of the subset and $3 \%$ of the total in the database as a whole) have more than ten editions. So, on the basis of this pattern, a logical

30 For Ariosto, the ratio is o.2. On the bibliography of the early editions of Ariosto, see Ulisse Guidi, Annali delle edizioni e delle versioni dell'Orlando Furioso e d'altri lavori al poema relativi (Bologna: Tipogr. in via Poggiale, 1861) and Giuseppe Agnelli and Giuseppe Ravegnani, Annali delle edizioni ariostee (Bologna: Zanichelli, 1933), to whom the works of Conor Fahy should be added, and above all his L“'Orlando furioso" del 1532. Profilo di una edizione (Milan: Vita e Pensiero, 1989). 
consequence would appear to be that a significant occurrence of unmatched editions is more notably found in quite a low percentage of the total sample under consideration, for which the probability of finding possible lost editions is therefore higher.

\section{Subset D: Authors above the Threshold Value}

Both these assumptions - the occurrence of unmatched editions in a low percentage of the total sample and the consequent higher probability of finding lost editions - are borne out by the analysis of the last subset of authors, those with a very high number of unmatched editions (subset D).

They number 937, i.e. just $17 \%$ of the total and among them less than half (439) vary significantly from the average, with a ratio between one and nine, while for the other 498 cases the average is fairly near to the standard measure. The subset is even more reduced if authors with fewer than ten unmatched editions are taken out. If this is done, just 197 authors remain, all of whom are highly exceptional either in terms of their ratio or in terms of the number of editions listed for them. They correspond to a mere $3.5 \%$ of the total number of authors, but overall 10,613 unmatched editions are related to them, amounting to almost half the total number of unmatched editions (table 15.1). ${ }^{31}$

This confirms that the filtering methodology is capable of identifying a restricted sample of statistically useful cases, thus contributing in a significant way to the study of the vast range of data contained in the database as a whole. ${ }^{32}$

In addition, it is important to observe that the filter not only works in quantitative terms, since subsequent analysis of external evidence can shows how the 'statistically useful data' obtained from the methodology can be significant for the identification of possible lost editions.

31 For reasons of space, table 15.1 shows a restricted list from subset D, including only those authors with ratios higher than 1.5; the total number of editions involved is 9,960 out of a total of 21,850 .

32 It should be noted that, to find more regular ratios, the sample should be differently considered: in fact the Pareto rule of $20: 80$ is verified if the abnormal ratio is set at 0.5 , with the inclusion of the statistical code of the previous set. There are 275 authors with a ratio higher than 0.5; if they are added to the 937 authors who have an average higher than 0.8 , the total $(1,212)$ is $22 \%$ of the total number of authors while the number of editions is 17,189 , i.e. $79 \%$ of the total 21,85 . It should also be pointed out that the median for the sample is in fact 0.67 , not 0.8 . 
In fact, if the subset list is sorted according to a decreasing ratio value, the Dominican preacher Girolamo da Palermo occupies first place, with ten known editions as opposed to ninety-one which are unmatched. ${ }^{33}$ This author has already attracted the attention of Rosa Marisa Borraccini who has studied the low survival rate of his editions, basing her findings on a comparison of information drawn from the RICI database with information taken from external sources. ${ }^{34}$ In this way the position of Girolamo da Palermo appears to parallel to some extent Ariosto's in the previous subset: the fact that this author heads the list serves as a confirmation that the methodology is working.

On the other hand, if we sort the list in decreasing order of the total number of editions for each author, the most prominent turns out to be the Catholic Church, with a very high number of unknown editions of liturgical books. ${ }^{35} \mathrm{In}$ this case, the reliability of the data is not supported by external evidence, as in the case of Girolamo da Palermo, but such a high rate of loss is extremely plausible when one takes into consideration the extent of liturgical publishing in the sixteenth century, the obvious interest of monastic libraries in acquiring this kind of material, and the degree of wear and tear to which liturgical books were subjected.

These results mean that we can use this subset in order to obtain a degree of positive data, even though this does not imply that all the evidence included in the subset is completely relevant in this context. As has already been pointed out, filtering data produces a short list of the most exceptional cases, those for which there is a higher probability of the presence of possible lost editions. Yet it is also obvious that analysing this data with this aim means first of all possibly identifying and then excluding bibliographical ghosts, since the methodology by itself is not able to reveal these.

For each of the authors in the subset the individual percentage of (hypothetically assumed) ghosts/lost editions will vary and will need to be analysed in detail. There may be cases where, after more accurate analysis, a large number of ghosts are detectable, thus drastically reducing the potential figure of lost editions. Averroes is an example: he is one of the authors with a higher ratio (5.3) and a higher number of editions too which for the most part, however, do not need to be taken into account. ${ }^{36}$ As his works were often described under generic titles (such as In Aristotelem or Commentaria or Opera) and often involve complex statements of responsibility (Averroes

\footnotetext{
33 Table 15.1, no. 26.

34 Borraccini, 'An Unknown Best-Seller'.

35 Table 15.1, no. 1.

$36 \quad$ Table 15.1, no. 37 .
} 
being a commentator but also commented on in his turn) - indeed his works could even be associated by topic in composite volumes - most of the unmatched editions under his name in the RICI database can perhaps more confidently be seen as cataloguing errors or subsequent issues rather than editions which have now been lost to us.

The methodological approach outlined here does not offer particular advantages in this respect (except that it enables us to monitor the most commonly found errors), but in any case examples such as Averroes are not problematic since they can either be resolved negatively (by identifying errors, issues, etc.) or cannot be resolved at all.

The problem arises with cases where presumed ghosts are less in evidence, so correspondingly increasing the potential number of authentically lost editions. In these cases analysis usually comes up against the weakness of the classical 'argumentum ex silentio': unknown editions in the database for which there is no plausible evidence of error or misunderstanding on the part of the cataloguer cannot, solely on the grounds that they are listed here, be assumed to be indications of genuinely lost editions.

Yet it is important also to point out that this methodological weakness is to some extent compensated for by numerical evidence. This is the case for example of the grammarian Luigi Antonio Sompano who, with a ratio of nine matched editions and forty-five unmatched editions, all sixteenth-century and Italian, is positioned in the table just after Girolamo da Palermo. ${ }^{37}$ Substantial errors of the kind just mentioned appear to be largely absent in the editions listed for this author; in addition, the data now available to us from Edit16 can be integrated, with a high degree of probability, with several of the unmatched editions. Among the forty-five unmatched editions in the RICI database there are, for example, seven published by Orazio Salviani dated between 1567 and $1594,{ }^{38}$ three by Cacchi dated between 1578 and 1580, ${ }^{39}$ three by Varisco (also in association with Paganini) dated 1575 and $1595,{ }^{40}$ and two by Ziletti dated 1582 and $1584 .{ }^{41}$ No Salviani, Cacchi, Varisco or Ziletti editions of Sompano's works are recorded in Edit16, where a mere twelve editions in total are recorded for

Table 15.1, no. 54. On the grammarian Luigi Antonio Sompano, called Sidicino (1496-1557), see Benedetto Croce, 'La tomba del grammatico Sidicino', in Benedetto Croce, Aneddoti di varia letteratura (Bari: Laterza, 1953), vol. I, pp. 387-395 and Carlo De Frede, I lettori di umanità nello studio di Napoli durante il Rinascimento (Naples: L'Arte Tipografica, 1960), pp. $26-28$.

38 RICI вIв 50764, 12484, 10485, 64470, 64374, 39694, 45481.

39 RICI BIB 45465, 46569, 9580.

40 RICI BIB $47975,53888,54217$.

41 RICI BIB 53866, 26245 . 
him. So it is legitimate to deduce from the overall data, even in the absence of any external evidence to confirm it, that Sompano was published more widely than the number of surviving editions would suggest.

In other cases the numerical evidence of unmatched editions serves to confirm the popularity of authors whose works were constantly being reprinted, by adding more details on possible unknown editions (or, perhaps more probably, unknown issues) to the current information we have on them. This is true of many of the philosophical, theological and pastoral authors who were especially relevant to the interests of the monastic libraries, such as - to quote just three cases listed in table 15.1 - Crisostomo Javelli, Francisco Toledo and Luis de Granada.

For Javelli, Edit16 registers a gap in the sequence of editions printed by Giovanni Maria Bonelli between 1555 and 1564 . This gap can be filled by seven references from the RICI database dated 1558, 1559, 1560, 1562, and 1563 respectively. ${ }^{42}$ Similarly the gaps between 1555 and 1567 and between $1567-1577$ in the sequence of editions of Javelli's works printed by Girolamo Scoto can be filled by five RICI references dated $1557,155^{8}, 1562,1565,1566^{43}$ and by four more dated $1568,1569,1572,1574 \cdot{ }^{44}$

In the case of Toledo, the already recorded editions by Girolamo Polo, dated $1579,1582,1600,{ }^{45}$ are supplemented by the RICI database with another seven, printed between 1576 and $1597^{46}$ The two editions known to have been published by Giacomo Tornieri ${ }^{47}$ are supplemented by six editions from the same publisher printed between 1578 and 1592, ${ }^{48}$ while at least seven are cited in the database for Girolamo Scoto and his heirs ${ }^{49}$ when no edition printed by the Scoto family is recorded in Edit16. Finally, in the case of Luis de Granada, two examples must suffice: there are nine Bertano editions cited in the database as having been printed between 1572 and $1598^{50}$ to add to the four recorded in Edit16, and four Tramezzino editions which are completely unknown to the Italian census. ${ }^{51}$

\footnotetext{
42 RICI вIв 21692, 21691, 40693, 37226, 50695, 48348, 11215.

43 RICI вIB 10056, 45931, 48311, 75151, 72969.

44 RICI вIB 60130, 14084, 72035, 58412.

45 Edit16 CNCE 35418, 35436, 35520.

46 RICI вIB 42318, 75570, 34006, 34005, 75166, 10330, 46994.

47 Edit16 CNCE 34433, 61537.

48 RICI BIB 12351, 39317, 75777, 75165, 50277, 76287.

49 RICI вів 33361, 33359, 3336o, 48310, 64098, 64096, 64097, 45207, 72092.

50 RICI вів 49747, 35507, 13139, 63887, 58450, 67789, 14602, 64540, 9895.

51 RICI вIB 40389, 22546, 39848, 7949.
} 
TABLE 15.1 The table lists authors with a ratio exceeding 1.5 and more than 10 unmatched editions. Columns show: unmatched editions (UE), matched editions $(M E)$, the ratio of the two values $(U E / M E)$ and the name of the authors given in the form used in the RICI database. The list is ordered by decreasing number of editions (matched plus unmatched)

\begin{tabular}{|c|c|c|c|c|}
\hline & UE & ME & UE/ME & NAME \\
\hline 1 & 704 & 453 & 1.5 & Chiesa Cattolica \\
\hline 2 & 257 & 148 & 1.7 & Antonino, santo \\
\hline 3 & 238 & $15^{1}$ & 1.6 & Azpilcueta, Martín de \\
\hline 4 & 180 & 89 & 2 & Toledo, Francisco \\
\hline 5 & 180 & 82 & 2.2 & Bonaventura da Bagnorea \\
\hline 6 & 186 & 66 & 2.8 & Duns Scotus, Ioannes \\
\hline 7 & $15^{8}$ & 92 & 1.7 & Iacopo da Varazze \\
\hline 8 & 141 & 93 & 1.5 & Concilio di Trento, $1545^{-1} 5^{6} 3$ \\
\hline 9 & 148 & 64 & 2.3 & Javelli, Giovanni Crisostomo \\
\hline 10 & 128 & 73 & 1.7 & Pepin, Guillaume \\
\hline 11 & 109 & 69 & 1.6 & Musso, Cornelio \\
\hline 12 & 104 & $5^{8}$ & 1.8 & Egidio Romano \\
\hline 13 & 99 & 63 & 1.6 & $\begin{array}{l}\text { Boethius, Anicius Manlius } \\
\text { Torquatus Severinus }\end{array}$ \\
\hline 14 & 116 & 45 & 2.6 & Jean de Jandun \\
\hline 15 & 118 & 34 & $3 \cdot 5$ & Dias, Filippe \\
\hline 16 & 102 & 48 & 2.1 & Vives, Juan Luis \\
\hline 17 & 110 & 38 & 2.9 & Loarte, Gaspar de \\
\hline 18 & 101 & 44 & 2.3 & Fumo, Bartolomeo \\
\hline 19 & 91 & 54 & 1.7 & Paolo Veneto \\
\hline 20 & 91 & 49 & 1.8 & Estella, Diego \\
\hline 21 & 81 & 46 & 1.7 & Albertus Magnus \\
\hline 22 & 85 & 38 & 2.2 & Tartaret, Pierre \\
\hline 23 & 77 & 45 & 1.7 & Angelo da Chivasso \\
\hline 24 & 66 & 43 & 1.5 & Soto, Domingo de \\
\hline 25 & 71 & 33 & 2.1 & Medina, Bartolomé de \\
\hline 26 & 91 & 10 & $9 \cdot 1$ & Girolamo da Palermo \\
\hline 27 & 63 & 38 & 1.6 & Pelbartus de Temeswar \\
\hline 28 & 70 & 29 & 2.4 & Morigia, Paolo \\
\hline 29 & 61 & 34 & 1.8 & Corradone, Matteo \\
\hline 30 & 60 & 35 & 1.7 & Incarnato, Fabio \\
\hline 31 & 64 & 30 & 2.1 & Venuti, Filippo \\
\hline 32 & 69 & 22 & 3.1 & Gerson, Jean Charlier de \\
\hline
\end{tabular}


TABLE 15.1 The table lists authors with a ratio exceeding 1.5 and more than 10 unmatched editions. (cont.)

\begin{tabular}{|c|c|c|c|c|}
\hline & UE & ME & UE/ME & NAME \\
\hline 33 & 68 & 22 & 3 & Berarducci, Mauro Antonio \\
\hline 34 & 64 & 24 & 2.7 & Calderari, Cesare \\
\hline 35 & 55 & 32 & 1.7 & Zimara, Marcantonio \\
\hline $3^{6}$ & 75 & 11 & 6.8 & Donatus, Aelius \\
\hline 37 & 69 & 13 & $5 \cdot 3$ & Averroes \\
\hline 38 & 57 & 25 & 2.3 & Burley, Walter \\
\hline 39 & 59 & 22 & 2.7 & Andrés, Antonio \\
\hline 40 & 57 & 21 & 2.7 & Nicolas de Lyre \\
\hline 41 & $5^{1}$ & 23 & 2.2 & Fiamma, Gabriele \\
\hline 42 & 41 & 27 & 1.5 & Denisse, Nicolas \\
\hline 43 & 49 & 18 & 2.7 & Pacifico da Novara \\
\hline 44 & 45 & 21 & 2.1 & Verrati, Giovanni Maria \\
\hline 45 & 44 & 21 & 2.1 & Pietro da Lucca \\
\hline 46 & 41 & 24 & 1.7 & Visdomini, Francesco \\
\hline 47 & 43 & 21 & 2 & Busti, Bernardino \\
\hline 48 & 44 & 18 & 2 & Ammiani, Sebastiano \\
\hline 49 & 39 & 23 & 1.7 & Priscianese, Francesco \\
\hline $5^{0}$ & 40 & 20 & 2 & Raulin, Jean \\
\hline $5^{1}$ & 46 & 10 & 4.6 & Franciscus de Mayronis \\
\hline $5^{2}$ & 35 & 20 & 1.7 & Pezzi, Lorenzo \\
\hline 53 & 33 & 20 & 1.6 & Viguier, Juan \\
\hline 54 & 45 & 5 & 9 & Sompano, Luigi Antonio \\
\hline 55 & 33 & 17 & 1.9 & Bartelon, Pantaléon \\
\hline $5^{6}$ & 33 & 15 & 2.2 & Ioannes Climacus,santo \\
\hline 57 & 31 & 17 & 1.8 & Barletta, Gabriele \\
\hline $5^{8}$ & 30 & 18 & 1.7 & Despautère, Jean \\
\hline 59 & 34 & 12 & 2.8 & Francisco de Osuna \\
\hline $6 o$ & 32 & 14 & 2.3 & Zarrabini, Onofrio \\
\hline 61 & 29 & 17 & 1.7 & Zabarella, Giacomo \\
\hline 62 & 28 & 18 & 1.5 & Giovanni da San Gimignano \\
\hline 63 & 32 & 12 & 2.7 & Thomas a Kempis \\
\hline 64 & 27 & 17 & 1.6 & Bersuire, Pierre \\
\hline 65 & 26 & 17 & 1.5 & Anglés, José \\
\hline 66 & 35 & 7 & 5 & Licheto, Francesco \\
\hline 67 & 28 & 14 & 2 & Piazzoni, Stefano \\
\hline
\end{tabular}




\begin{tabular}{|c|c|c|c|c|}
\hline & UE & ME & $\mathrm{UE} / \mathbf{M E}$ & NAME \\
\hline 68 & 30 & 10 & 3 & Guarino Veronese \\
\hline 69 & 27 & 9 & 3 & Trombetta, Antonio \\
\hline 70 & 22 & 13 & 1.7 & Agostiniani \\
\hline 71 & 25 & 8 & 3.1 & Ledesma, Diego de \\
\hline 72 & 20 & 13 & 1.5 & Besozzi, Giovanni Pietro \\
\hline 73 & 26 & 6 & $4 \cdot 3$ & Sirino, Girolamo, \\
\hline 74 & 21 & 11 & 1.9 & lberto da Padova \\
\hline 76 & 23 & 8 & 2.9 & Giovanni da L'Aquila \\
\hline 77 & 23 & 7 & 3.2 & Cantalicio, Giovanni Battista \\
\hline 78 & 20 & 10 & 2 & Anselmus, santo \\
\hline 79 & 19 & 11 & 1.7 & Osorio, Juan \\
\hline 80 & 21 & 8 & 2.6 & Filippo da Moncalieri \\
\hline 81 & 20 & 8 & 2.5 & Alexander de Ales \\
\hline 82 & 20 & 8 & 2.5 & Sibilla, Bartolomeo \\
\hline 83 & 19 & 8 & 2.4 & De Bonis, Emerio \\
\hline 84 & 18 & 9 & 2 & Boccadifuoco, Costanzo \\
\hline 85 & 18 & 9 & 2 & Achillini, Alessandro \\
\hline 86 & 21 & 5 & 4.2 & Francesco d'Assisi, santo \\
\hline 87 & 16 & 10 & 1.6 & Carcano, Michele \\
\hline 88 & 21 & 4 & $5 \cdot 2$ & Chaves, Tomaz de \\
\hline 89 & 16 & 9 & 1.8 & Boccadiferro, Lodovico \\
\hline 90 & 17 & 7 & 2.4 & Scarsella, Marco \\
\hline 91 & 16 & 8 & 2 & Trovamala, Battista \\
\hline 92 & 15 & 9 & 1.7 & Albertus de Saxonia \\
\hline 93 & 15 & 9 & 1.7 & Grosseteste, Robert \\
\hline 94 & 14 & 9 & 1.5 & Altenstaig, Johannes \\
\hline 95 & 14 & 8 & 1.7 & Ferrini, Vincenzo \\
\hline 96 & 14 & 7 & 2 & Joannes Canonicus \\
\hline 97 & 13 & 7 & 1.8 & Vallone, Giovanni \\
\hline 98 & 13 & 6 & 2.2 & Bartolomeo da Rinonico \\
\hline 99 & 12 & 7 & 1.7 & Verardi, Cipriano \\
\hline 100 & 13 & 5 & 2.6 & Gregorio da Napoli \\
\hline 101 & 12 & 6 & 2 & Bologna, Diocesi \\
\hline 102 & 11 & 7 & 1.5 & De Grassis, Padovano \\
\hline 103 & 11 & 7 & 1.5 & Casarubios, Alfonso de \\
\hline 104 & 11 & 7 & 1.5 & Giambelli, Cipriano \\
\hline 105 & 11 & 7 & 1.5 & Rainerius de Pisis \\
\hline
\end{tabular}


TABLE 15.1 The table lists authors with a ratio exceeding 1.5 and more than 10 unmatched editions. (cont.)

\begin{tabular}{lllll}
\hline & UE & ME & UE/ME & NAME \\
\hline 106 & 14 & 3 & 4.7 & Caprioli, Jean \\
107 & 12 & 5 & 2.4 & Offredi, Apollinare \\
108 & 11 & 6 & 1.8 & O'Fihely, Maurice \\
109 & 11 & 6 & 1.8 & Vincent de Beauvais \\
110 & 11 & 6 & 1.8 & Bosso, Matteo \\
111 & 13 & 3 & 4.3 & Antonio da Padova \\
112 & 11 & 5 & 2.2 & Maffei, Celso \\
113 & 11 & 5 & 2.2 & Vorilong, Guillaume de \\
\hline
\end{tabular}

It is probable that there are some bibliographical ghosts among all these, but it is also undeniable that the sheer quantity of editions in the RICI database which are unknown to us is convincing evidence they actually existed and encourages further research.

\section{Conclusions}

It is possible, I believe, to draw a positive conclusion from this brief survey. The proposed methodology appears to be effective in identifying subsets of data which can then be used in the search for lost editions. The numerical and statistical analysis of the library inventories compiled at the end of the sixteenth century for the Congregation of the Index can thus act as a compass in the dark bibliographical wood of lost books. A list of the most significant authors in subset $\mathrm{D}$ is given in Table 15.1, as a useful starting point for further analysis and research. 